\title{
Employment as a Factor of Life Quality
}

\author{
Tatjana Bilevičienè \\ Mykolas Romeris University \\ Vilnius, Lithuania \\ tbilev@mruni.eu \\ Eglè Bilevičiūtè \\ Mykolas Romeris \\ Vilnius, Lithuania \\ eglek@mruni.eu \\ Romualdas Drakšas \\ Mykolas Romeris University \\ Vilnius, Lithuania \\ draksas@tdd.lt
}

Abstract. Labour market functioning is affected by a number of internal and external factors. It is increasingly acknowledged that GDP should be associated with additional data and indicators. The effect of employment quality improvement on the quality of life is analysed in the study. The analysis of economic indicators enables not only evaluating the country's economic level, but also determine the relation between these factors, the condition of the labour market and the development of small and medium businesses. The article provides a theoretical analysis of the relation between employment and life quality. The empirical part analyses the results of the research "Labour, employment and entrepreneurship of the population", carried out under the commission of scientists, Mykolas Romeris University

Keywords: employment, quality of life, sustainable development, social policy

JEL classification: C1, J21.

\section{INTRODUCTION}

The issue of life quality improvement is becoming increasingly significant when solving most of the problems occurring in the society. This situation results from changes in social, economic, cultural, political and environmental situations. European Union (EU) and Lithuanian Normative Documents emphasize that economy is first of all a social process involving social subjects: people, social groups, institutions and the State. National and EU policy directions must be evaluated according to their progress in order to 
achieve social, economic and environmental goals, as well as improve the welfare of European citizens. The quality of life is usually understood as the level of welfare, individually perceived and evaluated as a way of life. The content of life quality is quite often identified as the concept of social welfare, by supplementing it with the country's economic development index - the size of gross domestic product (GDP) per each resident (Flynn at al., 2002; Dumbliauskienè, Jarmalavičienè, 2012). However, there is a widespread opinion that indicators illustrating economic achievements - GDP growth, GDP per resident, and other relative indicators associated with production factors, development of goods and services, and their monetary value, - no longer reflect the actual situation in a country, especially the standards of living and the welfare degree for an individual member of the society (Hagerty atal., 2001; Stiglitz at al., 2009). Indicators of life quality often do not depend on macroeconomic indicators, and may even negatively correlate with them. Thus, when evaluating the quality of life next to economic indicators, a significant role is also given to social, ecological, sustainable economic welfare indices focused on preservation of health, nature and healthy environment, clean production, renewable energy industry and organic farming (Lisauskaite, 2010). When analysing the development of life quality, each country should consider its own specific aspects, as the overall quality of life in each country can be influenced by different parameters, depending on country's level of development, geographical location, society's level of education and culture, political situation, historical era, mentality, religious views and other aspects.

The country's welfare depends on its economic and labour market policies, and also on its ability to ensure income for its people. Economic factor indicators describe the State's economic situation. These indicators also include employment and unemployment level indicators. It can be observed that there is a relation between employment/ quality of employment and evaluation of life quality. In 2011, European Union's growth strategy Europe 2020 was announced. "Europe 2020 puts forward three mutually reinforcing priorities:

Smart growth: developing an economy based on knowledge and innovation.

Sustainable growth: promoting a more resource efficient, greener and more competitive economy.

Inclusive growth: fostering a high-employment economy delivering social and territorial cohesion." (European Commission, 2010).

The Europe 2020 strategy emphasizes the social policy priority, and particular attention is paid to labour and employment, as well as the development of human resources. It can be stated that when evaluating only quantitative indicators of employment and unemployment, poor quality employment is often disregarded. Economic and social policy displays itself through the quality of employment, which is a wider indicator of economy as compared to the level of unemployment.

When implementing the project "Development of a system and evaluation model of indicators measuring the quality of life of Lithuanian people", the public opinion \& market research centre VILMORUS carried out a research "Labour, employment and entrepreneurship of population" under the commission of scientists, Mykolas Romeris University. The article analyses the research results characterizing employment and population employment quality, as well as their relation with the evaluation of life quality.

\section{CORRELATIONS BETWEEN EMPLOYMENT AND THE QUALITY OF LIFE}

EU employment policy is focused on the improvement of the European social model. Development of the necessary productive employment opportunities and ensuring steady livelihood are one of the most important and most difficult tasks of each society. Inclusion of as much people as possible into good quality employment is the best way of increasing their economic and social opportunities, as well as social cohesion. The country's welfare depends on its economic and labour market policy, and from its ability to ensure in- 
come for its people (Dromantiené,2008). Employment is the most important method to fully, actively and on equal rights participate in the life of the society. The more people participate full-time or part-time in the labour market, the larger their contribution to ensuring the accessibility of the necessary social security.

The last economic crisis affected not only the economic condition of the European Union, but also the social sphere, the labour market and employment. In 2013, the European Commission Employment Report (European Commission, 2013) stated that: "Unemployment has reached unprecedented levels in the EU-28. While the unemployment rate decreased by over 2 percentage points between 2003 and 2008, the financial and economic crisis has caused a severe deterioration. Between 2008 and the second quarter of 2013 the unemployment rate in the EU-28 increased from 7.1\% to 10.9\%". However, in 2015, the Eurofound Report (Eurofound, 2015) stated that: "Europe has begun to emerge from the prolonged slump that began with the global financial crisis in 2008 and was deepened by the euro zone single -currency crisis in 2010-2011. In the last year, aggregate employment levels have risen faster than at any time since 2008. Aggregate EU unemployment rates have been declining since September 2013".

When analysing the dynamics of employment and unemployment rates in Lithuania (see Fig.1), it can be observed that these rates improved between 2010 and 2013, even though in 2014-2015 the level of employment slightly decreased, however, the level of unemployment continued to decrease. The European Commission found that unemployment at the time mostly decreased in the Baltic States, Ireland and Hungary. Such differences are more or less in line with the GDP changes in the Member States (European Commission, 2013). Employment level trends continue to be unfavourable in order to reach the objective of ensuring the employment of 75 percent of the population between the ages of 20-64, as established in the Europe 2020 strategy. In order to solve the issue of the increasing queues of the unemployed, which in some Member States might pose a real threat to the harmony of the society and sustainable economic growth, it is necessary to create more jobs. However, with the growing integrated world economy, Europe needs to create not only more jobs, but these jobs need to also be better and more efficient in order to once again achieve progress by improving the living conditions of its citizens (Employment polarisation..., 2013).

Kirsten Sehnbruch (2004) states that the quality of employment has the same significance as the extent of employment. The quality of employment is a function of many factors. It mostly depends on circumstances and the personal needs of employees, thus it is necessary to apply criteria which are completely subjective, for example, job satisfaction, career opportunities, job stability, level of responsibility, interest in the job. Other important factors are management quality, acknowledgment of the efforts of employees, training and improvement opportunities, balance between work and rest, and relationships with colleagues. Evaluation of the quality of employment is often subjective. It can even differ in the same country, depending on the level of income (Anderson et al. 2010). Richard Layard (2005) states that evaluation of the quality of employment must include not only wages, working conditions and working hours, but also the level of job satisfaction. Measurements of the quality of employment can be determined from population surveys. 


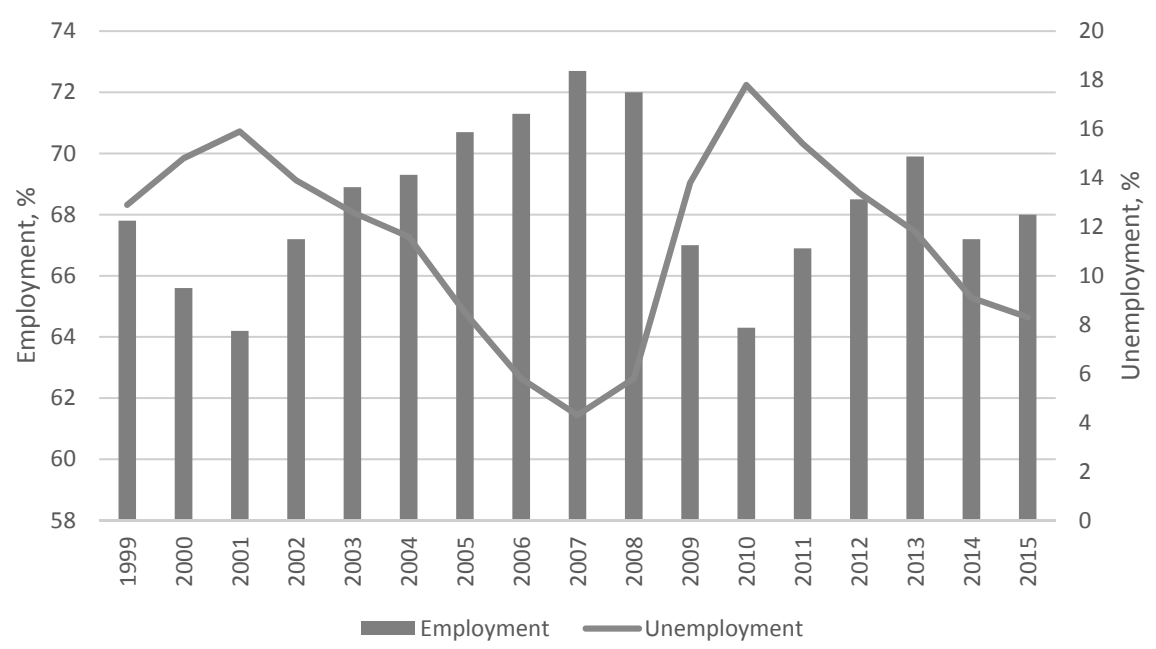

Figure 1. The level of employment and unemployment in Lithuania (Statistics Lithuania, 2016) Source: compiled by the authors according to Statistics Lithuania (2016).

The European Foundation for the Improvement of Living and Working Conditions (http://www.eurofound.europa.eu) developed an employment quality model and proposed its employment quality measurement indicators (European Foundation for the Improvement..., 2002). The most important employment quality indicators of the European Foundation can be divided into two groups: job quality indicators - job satisfaction, salary, working hours, skills and training, career opportunities, work content, appropriate potential of the employee to carry out his job; employment indicators in a wider labour market context equality, health and safety, flexibility and security, job availability, balance between work and life, employee's participation in the social dialogue, diversity and discrimination prevention, productivity of the economic activity (Commissions of the European Communities, 2001). Scientists from New Zealand carried out a study on the quality of employment (Career Progression and Development Survey, 2005). It should be noted that the feeling of success, the demonstration of skills and potentials, and effective management were more important than salary and career opportunities for most of the respondents. A flexible work schedule was very important for more than half of all the respondents.

Some authors (Răileanu Szeles, 2009) point out the correlation between the quality of employment and other employment factors in the European employment strategy, for example, the synergy of full employment, inclusion and social cohesion. Investments in the human capital and vocational training or improving the organization of work may encourage innovative activities and productivity growth.

Quality of life has been the object of a large amount of studies in different research areas such as economics, sociology, political science, psychology, philosophy and medical sciences. "Quality of life is an evolving idea which changes across time and societies and in relation to the population, cultures, living conditions and styles taken into consideration" (Vesan, Bizzotto, 2011). The quality of life covers a very wide area of political and economic interests. The work programme of the European Foundation for the Improvement of Living and Working Conditions (Eurofound) ${ }^{1}$ emphasizes the need to link the evaluation of the quality of life with the balance between employment, work and life, and social cohesion (Second European Quality

1 Eurofound. http://www.eurofound.europa.eu/ 
of Life Survey, 2009). The work programme of the European Foundation for the Improvement of Living and Working Conditions also emphasizes the need to link the evaluation of the quality of life with the variable nature of the balance between employment, work and life, and social cohesion (European Foundation ..., 2009). The opinion of the European Parliament regarding GDP and other indicators evaluating the progress in the changing world (European Parliament, 2010) specifies that GDP is the main indicator on the basis of which it is possible to properly consider the different social and economic characteristics at the European level, therefore it must remain the main criterion on the level of financial allocations, when implementing the future cohesion policy. However, it is increasingly acknowledged that GDP should be associated with additional data and indicators. Scientists (Mackonis, 2012; Norberg, 2010; Stiglitz at al., 2009) believe that GDP growth does not show whether the people are satisfied with their life, therefore other indicators must also be applied in order to measure the country's progress. In its communiqué GDP and other indicators for the evaluation of progress in the changing world, the Commission of the European Communities (2009) states that measures of ensuring the quality of life and welfare include income, public services, health, leisure, wealth, mobility and a clean environment. Thus, indicators related to these causative factors are very important for both the governments and the EU.

Quality of life indicators is a Eurostat online publication providing recent statistics on the quality of life in the European Union (Eurostat Statistics Explained). The authors found that a strong negative correlation exists between the quality of life indicators and the level of unemployment in Lithuania (Pearson correlation coefficient $r=-0,88$ ).

\section{EMPIRICAL RESEARCH METHODOLOGY}

A group of scientists from Mykolas Romeris University carried out a project in 2014 "Development of a system and evaluation model of indicators measuring the quality of life of Lithuanian people". When preparing the project, several indicator groups were distinguished, one of which was work and employment which also largely influence other indicators of the quality of life. The public opinion and market research centre VILMORUS carried out a research on April 11 - 23 of 2014 "Labour, employment and entrepreneurship of the population" under the commission of Mykolas Romeris University. Number of respondents $\mathrm{N}=1002$. Research object: residents of Lithuania who are 18 years and over, survey method: interview at the home of the respondent. Selection method: multilevel, probability sampling. Respondent selection is prepared so that each resident of Lithuania would have an equal chance of being surveyed. The research was carried out in 20 cities/towns and 29 villages. The article includes a data analysis of the "Labour and Employment of the Population" research part.

Research aim: to evaluate the influence of employment and the quality of employment on the quality of life.

Research methods: statistical data analysis. Descriptive statistics method, relations analysis (Pearson $\chi^{2}$ criterion calculation), correlation analysis (Pearson and Spearman correlation coefficient calculation) and multidimensional statistical analysis were applied. Pearson $\chi^{2}$ criterion calculation is applied to nominal variables, Pearson correlation coefficient is calculated by determining the relation of quantitative variables, Spearman correlation coefficient is calculated by determining the relation of ordinal variables. 


\section{EMPIRICAL RESEARCH RESULTS}

The analysis of the research results revealed that 41,3 percent of respondents were unemployed, 8,8 percent worked less than full-time, 44,1 percent worked full-time, and 5,8 percent of respondent worked more than full-time. Pearson $\chi^{2}$ criterion calculation shows that employment (regardless of whether the respondent is unemployed, works full-time, or works less or more than full-time) does not depend on gender. This confirms the opinion of the European Commission that the employment of men and women is equal in Lithuania. Employment depends on age, place of residence and marital status ( $p$-level $=0,000$ ).

\subsection{Analysis on the interdependence of employment factors}

Pearson $\chi^{2}$ criterion calculation was applied in order to determine the interdependence of employment factors (see Table 1). It can be observed that the labour sector (public, private, public and private) has no relation neither to employment (unemployed, working full-time, working less than full-time, working more than full-time), nor to the nature of work (permanent job, fixed-term contract, hourly work, seasonal work and other paid activities), nor to the possibility to practice one's profession (had to requalify, the job partly matches one's qualifications, the job fully matches one's qualifications, job includes tasks that both match and do not match the employee's qualifications).

Table 1

Interdependence of employment factors

\begin{tabular}{|c|c|c|c|c|}
\hline & $\begin{array}{l}\text { Employment } \\
\text { (unemployed, } \\
\text { working full- } \\
\text { time, working } \\
\text { less than full- } \\
\text { time, working } \\
\text { more than } \\
\text { full-time) }\end{array}$ & $\begin{array}{c}\text { Nature of } \\
\text { work (per- } \\
\text { manent job, } \\
\text { fixed-term } \\
\text { contract, } \\
\text { hourly work, } \\
\text { seasonal work } \\
\text { and other paid } \\
\text { activities) }\end{array}$ & $\begin{array}{l}\text { Labour sec- } \\
\text { tor (public, } \\
\text { private, public } \\
\text { and private) }\end{array}$ & $\begin{array}{l}\text { Possibility to } \\
\text { practice one's } \\
\text { profession (had } \\
\text { to requalify, the } \\
\text { job partly matches } \\
\text { one's qualifica- } \\
\text { tions, the job } \\
\text { fully matches one's } \\
\text { qualifications, } \\
\text { job includes tasks } \\
\text { that both match } \\
\text { and do not match } \\
\text { the employee's } \\
\text { qualifications). }\end{array}$ \\
\hline $\begin{array}{l}\text { Employment (unemployed, working full-time, } \\
\text { working less than full-time, working more than } \\
\text { full-time) }\end{array}$ & & $\begin{array}{c}\text { depends } \\
\text { p-level }= \\
0,000\end{array}$ & $\begin{array}{l}\text { does not } \\
\text { depend }\end{array}$ & $\begin{array}{c}\text { depends } \\
p \text {-level }=0,000\end{array}$ \\
\hline $\begin{array}{l}\text { Nature of work (permanent job, fixed-term } \\
\text { contract, hourly work, seasonal work and other } \\
\text { paid activities) }\end{array}$ & $\begin{array}{c}\text { depends } \\
p \text {-level }=0,000\end{array}$ & & $\begin{array}{l}\text { does not } \\
\text { depend }\end{array}$ & $\begin{array}{c}\text { depends } \\
\text {-level }=0,000\end{array}$ \\
\hline $\begin{array}{l}\text { Labour sector (public, private, public and } \\
\text { private) }\end{array}$ & $\begin{array}{l}\text { does not } \\
\text { depend }\end{array}$ & $\begin{array}{l}\text { does not } \\
\text { depend }\end{array}$ & & does not depend \\
\hline $\begin{array}{l}\text { Possibility to practice one's profession (had to } \\
\text { requalify, the job partly matches one's qualifi- } \\
\text { cations, the job fully matches one's qualifica- } \\
\text { tions, job includes tasks that both match and do } \\
\text { not match the employee's qualifications). }\end{array}$ & $\begin{array}{c}\text { depends } \\
p \text {-level }=0,000\end{array}$ & $\begin{array}{c}\text { depends } \\
\text { p-level }= \\
0,000\end{array}$ & $\begin{array}{l}\text { does not } \\
\text { depend }\end{array}$ & \\
\hline
\end{tabular}

Source: compiled by the authors. 
Employment (unemployed, working full-time, working less than full-time, working more than full-time) has a relation to the nature of work (permanent job, fixed-term contract, hourly work, seasonal work and other paid activities) and to the possibility to practice one's profession (had to requalify, the job partly matches one's qualifications, the job fully matches one's qualifications, job includes tasks that both match and do not match the employee's qualifications). It can be stated that, in order to work, respondents have to either requalify or choose a temporary job position. Otherwise they might be unemployed. In order to find a job (part-time or full-time), a large part of the respondents requalified. However, respondents who work more than full-time have jobs that match their qualifications.

Also, the nature of work (permanent job, fixed-term contract, hourly work, seasonal work and other paid activities) has a relation to the possibility to practice one's profession (had to requalify, the job partly matches one's qualifications, the job fully matches one's qualifications, job includes tasks that both match and do not match the employee's qualifications). In this case, it can be stated that high flexibility of the labour market is necessary.

\subsection{Job satisfaction analysis}

Respondents were presented with the question: "What is your opinion on your job (if you are currently employed)?" and job quality factors were provided for evaluation (see Table 2). Respondents had to evaluate the importance of these factors and their satisfaction with these factors. Spearman correlation coefficient $(r)$ calculation revealed a very weak correlation between the importance of the factors and the satisfaction with these factors evaluation (see Table 1). An average correlation exist only between the possibility to have a job that the person enjoys $\left(r_{s}=0,326\right)$, relationship with the manager $\left(r_{s}=0,379\right)$, relationships with co-workers $\left(r_{s}\right.$ $=0,414)$ and the possibility to use one's abilities creatively $(0,398)$, under the evaluation of the importance of the factors and the satisfaction with these factors. We can see that these are the factors that rather strongly depend on the working persons themselves.

Relation between the importance of job factors and the satisfaction with these factors

\begin{tabular}{|l|c|}
\hline & $\begin{array}{c}\text { Are these factors important to you?/ } \\
\text { Are you satisfied with these aspects? }\end{array}$ \\
\hline Possibility to have a job that you would enjoy & $r_{s}=0,326 ; p$-level $=0,000$ \\
\hline Possibility to maintain your current job position & $r_{s}=0,274 ; p$-level $=0,000$ \\
\hline Salary & no relation \\
\hline Relationship with the manager, management & $r_{s}=0,379 ; p$-level $=0,000$ \\
\hline Relationships with co-workers & $r_{s}=0,414 ; p$-level $=0,000$ \\
\hline Healthy working conditions, prevention of stress & $r_{s}=0,172 ; p$-level $=0,000$ \\
\hline The possibility to balance work, leisure and family obligations & $r_{s}=0,207 ; p$-level $=0,000$ \\
\hline The possibility to use your abilities creatively & $r_{s}=0,398 ; p$-level $=0,000$ \\
\hline The possibility to progress further in your career & $r_{s}=0,273 ; p$-level $=0,000$ \\
\hline The possibility to improve and raise your qualification & $r_{s}=0,295 ; p$-level $=0,000$ \\
\hline The possibility to have free time after work, to rest & $r_{s}=0,285 ; p$-level $=0,000$ \\
\hline Work in general & $r_{s}=0,294 ; p$-level $=0,000$ \\
\hline
\end{tabular}

Source: compiled by the authors. 
Respondents evaluated the importance of their job factors and the satisfaction with these factors based on a five-point system, where 1 is the worst evaluation, and 5 is the best evaluation. An average rating of the evaluation of these factors was calculated (see Table 3 and Fig.2)

Table 3

The importance of job factors and the satisfaction with these factors

\begin{tabular}{|l|c|c|}
\hline & $\begin{array}{c}\text { Evaluation average } \\
\text { (importance) }\end{array}$ & $\begin{array}{c}\text { Evaluation average } \\
\text { (satisfaction) }\end{array}$ \\
\hline Salary & 4,64 & 3,42 \\
\hline Work in general & 4,64 & 4,04 \\
\hline The possibility to have free time after work, to rest & 4,6 & 4 \\
\hline Relationships with co-workers & 4,56 & 4,16 \\
\hline Possibility to have a job that you would enjoy & 4,56 & 3,92 \\
\hline The possibility to balance work, leisure and family obligations & 4,55 & 3,9 \\
\hline Possibility to maintain your current job position & 4,51 & 4,02 \\
\hline Relationship with the manager, management & 4,5 & 3,96 \\
\hline Healthy working conditions, prevention of stress & 4,5 & 3,64 \\
\hline The possibility to go on paid/unpaid leave & 4,31 & 3,92 \\
\hline The possibility to improve and raise your qualification & 4,26 & 3,54 \\
\hline The possibility to use your abilities creatively & 4,22 & 3,68 \\
\hline The possibility to progress further in your career & 3,9 & 3,36 \\
\hline
\end{tabular}

Source: compiled by the authors.

The averages of the evaluation of the importance of factors of respondents show that salary and work in general are the most important (4,64 points). However, the evaluation of salary satisfaction is the lowest of all $(3,42$ points). The least important is the possibility to progress further in one's career, and the satisfaction with this factor is the lowest as well. The importance of relationships with co-workers was evaluated equally with the importance of the possibility to have a job that one would enjoy ( 4,56 points). However, if satisfaction with the relationships with co-workers is evaluated relatively highly (4,16 points), then satisfaction with the possibility to have a job that one would enjoy is evaluated only with 3,92 points. The evaluation of the possibility to have free time after work and to rest is higher (4,6 points) compared to the possibility to have a job that one would enjoy. Apparently, when choosing a job, respondents aim to achieve this, as the satisfaction with the possibility to have free time after work and to rest is higher. The importance of the possibility to maintain one's current job position ( 4,51 points) is lower than the possibility to balance work, leisure and family obligations (4,55 points). This shows that family relations have a priority against employment. However, satisfaction with the possibility to balance work, leisure and family obligations is much lower (3,9 points). 


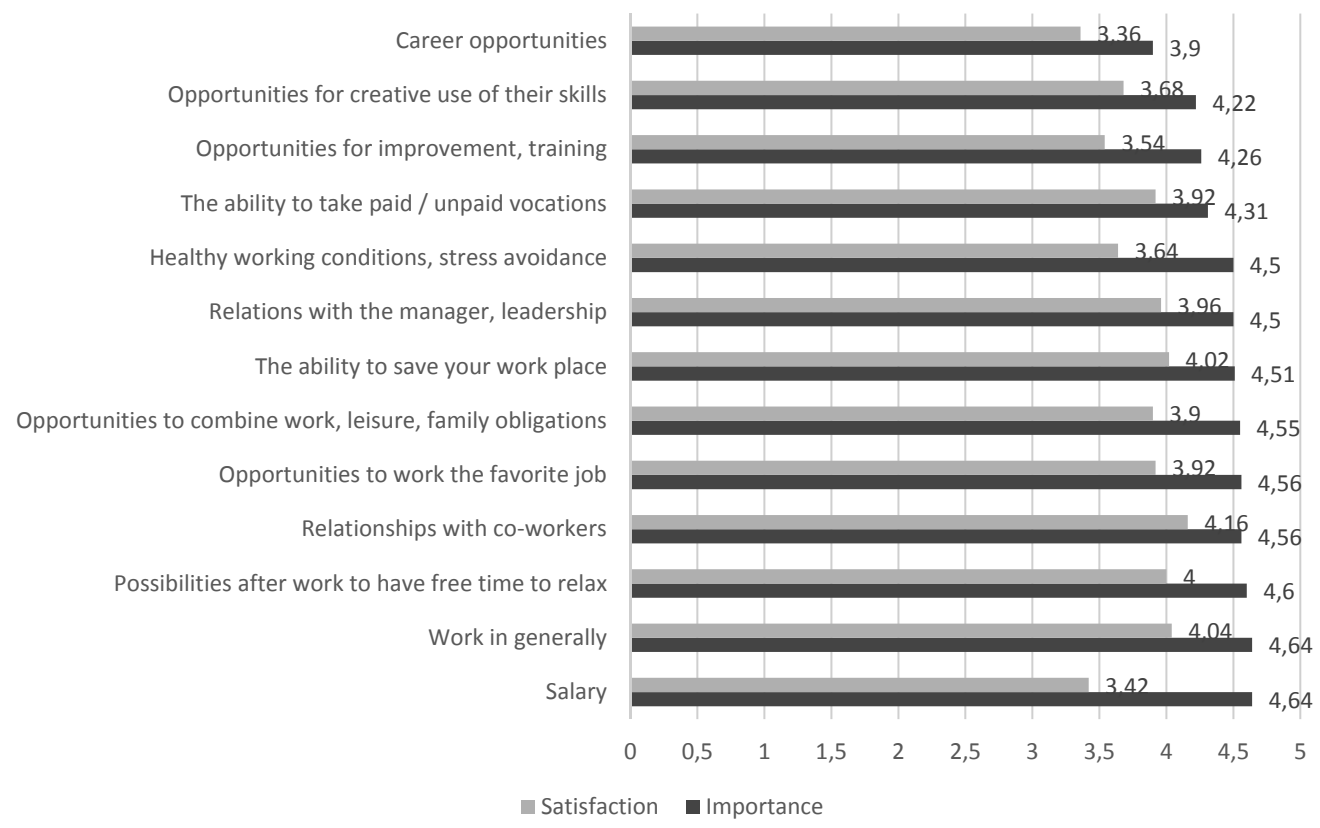

Figure 2. The importance of job factors and the satisfaction with these factors

Source: own calculation.

Even though the evaluation of the importance of the possibility to improve and raise qualification (4,26 points), and the possibility to use one's abilities creatively (4,22 points) is not high, the evaluation of the satisfaction with these factors is even lower (3,54 and 3,68 points accordingly). The importance of relationships with co-workers (4,56 points) is evaluated better than the importance of the relationship with the manager ( 4,5 point), however the satisfaction with the relationship with the manager is also much lower (3,96 points). To sum up, it can be stated that the importance of most factors is evaluated by more than 4,5 points, but the satisfaction with these factors is evaluated by mostly less than 4 points.

Spearman correlation coefficient $(r)$ calculation was applied when analysing the correlation of job factor importance.(see Table 4).

The average relation of the evaluation of the importance of these factors can be seen. The strongest correlation exists between the relationship with the manager and relationships with co-workers $\left(r_{s}=0,705\right)$, the possibility to progress further in one's career, the possibility to improve and raise one's qualification $\left(r_{s}\right.$ $=0,691)$, the possibility to balance work, leisure and family obligations, healthy working conditions, prevention of stress $\left(r_{s}=0,596\right)$, relationships with co-workers and the possibility to balance work, leisure and family obligations $\left(r_{s}=0,584\right)$, under the evaluation of their importance. All these correlations are logical. 
Table 4

The correlation of job factor importance (Spearman correlation coefficient $r$, $p$-level $=0,000$ )

\begin{tabular}{|c|c|c|c|c|c|c|c|c|c|c|c|c|}
\hline & 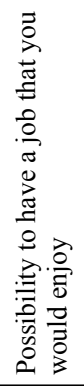 & 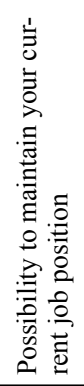 & 善 & 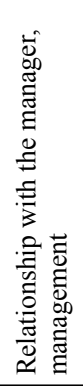 & 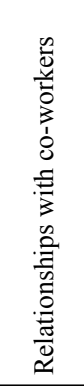 & 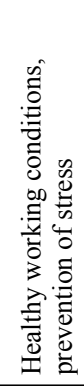 & 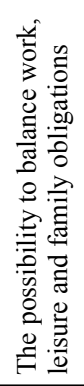 & 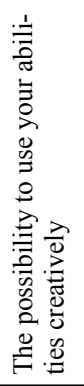 & 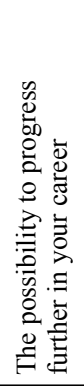 & 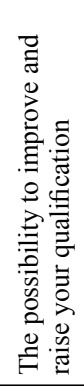 & 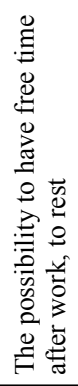 & 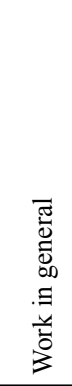 \\
\hline $\begin{array}{l}\text { Possibility to } \\
\text { have a job that } \\
\text { you would enjoy }\end{array}$ & & 0,456 & 0,456 & 0,520 & 0,498 & 0,424 & 0,485 & 0,484 & 0,375 & 0,460 & 0,425 & 0,465 \\
\hline $\begin{array}{l}\text { Possibility to } \\
\text { maintain your } \\
\text { current job } \\
\text { position }\end{array}$ & 0,456 & & 0,391 & 0,444 & 0,497 & 0,368 & 0,385 & 0,301 & 0,314 & 0,335 & 0,369 & 0,435 \\
\hline Salary & 0,456 & 0,391 & & 0,494 & 0,472 & 0,498 & 0,435 & 0,280 & 0,239 & 0,286 & 0,440 & 0,425 \\
\hline $\begin{array}{l}\text { Relationship with } \\
\text { the manager, } \\
\text { management }\end{array}$ & 0,520 & 0,444 & 0,494 & & 0,705 & 0,476 & 0,535 & 0,421 & 0,386 & 0,424 & 0,475 & $\mathbf{0 , 5 0 1}$ \\
\hline $\begin{array}{l}\text { Relationships } \\
\text { with co-workers }\end{array}$ & 0,498 & 0,497 & 0,472 & 0,705 & & $\mathbf{0 , 5 4 5}$ & 0,584 & 0,411 & 0,354 & 0,400 & 0,458 & 0,481 \\
\hline $\begin{array}{l}\text { Healthy working } \\
\text { conditions, pre- } \\
\text { vention of stress }\end{array}$ & 0,424 & 0,368 & 0,498 & 0,476 & 0,545 & & 0,596 & 0,404 & 0,341 & 0,317 & 0,470 & 0,397 \\
\hline $\begin{array}{l}\text { The possibility } \\
\text { to balance work, } \\
\text { leisure and fam- } \\
\text { ily obligations }\end{array}$ & 0,485 & 0,385 & 0,435 & 0,535 & 0,584 & 0,596 & & 0,516 & 0,369 & 0,445 & 0,569 & 0,497 \\
\hline $\begin{array}{l}\text { The possibility to } \\
\text { use your abilities } \\
\text { creatively }\end{array}$ & 0,484 & 0,301 & 0,28 & 0,421 & 0,411 & 0,404 & 0,516 & & 0,486 & 0,545 & 0,432 & 0,370 \\
\hline $\begin{array}{l}\text { The possibility to } \\
\text { progress further } \\
\text { in your career }\end{array}$ & 0,375 & 0,314 & 0,239 & 0,386 & 0,354 & 0,341 & 0,369 & 0,486 & & 0,691 & 0,399 & 0,377 \\
\hline $\begin{array}{l}\text { The possibil- } \\
\text { ity to improve } \\
\text { and raise your } \\
\text { qualification }\end{array}$ & 0,46 & 0,335 & 0,286 & 0,424 & 0,4 & 0,317 & 0,445 & 0,545 & 0,691 & & 0,477 & 0,464 \\
\hline $\begin{array}{l}\text { The possibil- } \\
\text { ity to have free } \\
\text { time after work, } \\
\text { to rest }\end{array}$ & 0,425 & 0,369 & 0,44 & 0,475 & 0,458 & 0,47 & 0,569 & 0,432 & 0,399 & 0,477 & & 0,538 \\
\hline Work in general & 0,465 & 0,435 & 0,425 & 0,501 & 0,481 & 0,397 & 0,497 & 0,37 & 0,377 & 0,464 & 0,538 & \\
\hline
\end{tabular}

Source: compiled by the authors. 


\subsection{Analysis of employment relation with some other factors of the quality of life}

Questionnaire block "Consumption" included the following question: "To what extent are you satisfied with your consumption and purchase possibilities?". With the help of Pearson $\chi^{2}$ criterion, the correlation of the satisfaction with one's consumption and purchase possibilities and employment factors was analysed.

Satisfaction with one's consumption and purchase possibilities depends on employment (unemployed, working full-time, working less than full-time, working more than full-time) $(p$-level $=0,000)$. It can be observed that very few respondents are highly satisfied with their consumption and purchase possibilities. Respondents mostly declared average satisfaction. Most of those who are unsatisfied are unemployed, although there were quite a few unemployed respondents who are averagely satisfied or satisfied with their consumption and purchase possibilities. This shows that personal employment does not always reflect the true standard of living. Satisfaction with one's consumption and purchase possibilities does not depend on the labour sector (public, private, public and private).

Questionnaire block "Happiness of life" included the question "Do you agree or disagree with the following statements: I have clear life goals; I am a happy person".

With the help of Pearson $\chi^{2}$ criterion, the correlation of these happiness evaluation factors with employment factors was analysed.

The evaluation of the statement "I am a happy person" is correlated to employment (unemployed, working full-time, working less than full-time, working more than full-time) ( $p$-level $=0,000)$. The evaluation of the statement "I have clear life goals" is correlated to employment (unemployed, working full-time, working less than full-time, working more than full-time) $(p$-level $=0,000)$. The possibility to practice one's profession (had to requalify, the job partly matches one's qualifications, the job fully matches one's qualifications, job includes tasks that both match and do not match the employee's qualifications) is correlated to the evaluation of the statement "I have clear life goals" ( $p$-level $=0,000)$.

Research results have shown that most of the respondents have clear life goals. However, it can be observed that life goals can be understood differently. For example, the number of respondents who had life goals was equal among the unemployed and those working full-time. The number of respondents who had goals was also similar among those who practice their profession and those who had to requalify.

The importance of employment was analysed based on the employment factors. With the help of Pearson $\chi^{2}$ criterion, it was determined that the importance of employment to the respondent depends on his employment (the respondent is unemployed, working full-time, working less than full-time, working more than full-time $(p$-level $=0,000)$.

The importance of employment does not depend on the nature of work (permanent job, fixed-term contract, hourly work, seasonal work and other paid activities), labour sector (public, private, public and private), the possibility to practice one's profession (had to requalify, the job partly matches one's qualifications, the job fully matches one's qualifications, job includes tasks that both match and do not match the employee's qualifications).

The analysis of these factors is not comprehensive and was carried out as an example of the relation between employment and the quality of life. This research material enables to continue analysing the relation of employment and the quality of employment with the factors of the quality of life.

\section{CONCLUSION}

Development of the necessary productive employment opportunities and ensuring steady livelihood are one of the most important and most difficult tasks of each society. The country's welfare depends on its 
economic and labour market policy, and from its ability to ensure income for its people. To ensure equal opportunities for all, employment is a very significant factor contributing to the full participation of citizens in economic, cultural and social life, as well as to the implementation of their opportunities. The quality of employment has the same significance as the extent of employment. The quality of employment is a wide concept, because the quality of employment also depends on the characteristics of a workplace, on salary, on the possibility to progress further in one's career, to meet one's expectations, and it also depends on subjective psychological matters - relationships with co-workers, relationships with superiors and the satisfaction with one's own life.

Currently, GDP is considered to be not only an indicator of economic development, but also an indirect indicator of social development and progress in a broad sense. However, it is increasingly acknowledged that GDP should be associated with additional data and indicators.

A group of scientists from Mykolas Romeris University carried out a project in 2014 "Development of a system and evaluation model of indicators measuring the quality of life of Lithuanian people". The public opinion and market research centre VILMORUS carried out a research on April $11-23$ of 2014 "Labour, employment and entrepreneurship of the population" under the commission of Mykolas Romeris University. An analysis of the research results enabled to evaluate the effect on employment and the quality of employment on the quality of life in Lithuania.

The general employment data analysis shows that employment (whether the respondent is unemployed, working full-time, working less than full-time, working more than full-time) does not depend on gender, however it depends on age, place of residence and marital status. The nature of work (permanent job, fixedterm contract, hourly work, seasonal work and other paid activities) depends on age, but does not depend on gender, place of residence and marital status. The labour sector (public, private, public and private) does not depend on the place of residence and marital status, but depends on gender and age. The possibility to practice one's profession (had to requalify, the job partly matches one's qualifications, the job fully matches one's qualifications, job includes tasks that both match and do not match the employee's qualifications) depends only on gender, and does not depend on age, place of residence and marital status. The correlation between employment factors can also be observed.

General work experience is correlated with employment, the nature of work and the labour sector. The possibility to practice one's profession has no relation with work experience.

An analysis on the job satisfaction factors and an analysis on the relation of employment with the other factors of the quality of life were carried out. It was determined that the evaluation of the importance of job factors differs from the satisfaction with these factors. Factor importance was evaluated between 4,2 and 4,6 points out of 5 possible points. Satisfaction with these factors was evaluated between 3,4 and 4 points out of 5 possible points. This shows that satisfaction with employment factors is average in Lithuania.

Employment is related to the feeling of happiness, optimism and other factors of the quality of life. The analysis of these factors is not comprehensive and was carried out as an example of the relation between employment and the quality of life. This research material enables to continue analysing the relation of employment and the quality of employment with the factors of the quality of life. 


\section{REFERENCES}

Anderson, L., Clogston F., Erekat D., Garmise S., Ghosh, S., Girdwood C., Mulclaire C., and Thorstensen L. (2010), Creating Quality Jobs: Transforming the Economic Development Landscape, Danville, CA: International Economic Development Council.

Career Progression and Development Survey (2005) // http://www.ssc.govt.nz/display/document.asp?docid=5310\&pag eno=18\#P3046_349561 (refered on 15/02/2016).

Commission of the European Communities (2001), Employment and social policies: a framework for investing in quality. Communication from the Commission to the Council, the European Parliament, the Economic and Social Committee and the Committee of the Regions, COM (2001) 313 final, CELEX No 52001DC0313.

Commission of the European Communities (2009), Communication from the Commission to the Council and the European Parliament. GDP and beyond Measuring progress in a changing world, COM(2009) 433 final // http://eur-lex.europa. eu/LexUriServ/LexUriServ.do?uri=COM:2009:0433:FIN:lt:PDF (refered on 15/02/2016).

Dromantienè, L. (2008), Socialinès Europos kürimas, Vilnius.

Dumbliauskienè, M., Jarmalavičienė, S. (2012), Gyvenimo kokybès kompleksinio vertinimo metodologinès problemos, Geografijos metraštis, no. 45, pp. 3-14.

Employment polarisation and job quality in the crisis: European Jobs Monitor 2013. Executive summary (2013) // http://www.eurofound.europa.eu/pubdocs/2013/041/en/1/EF13041EN.pdf (refered on 15/02/2016).

European Foundation for the Improvement of Living and Working Conditions (2002), Quality of work and employment in Europe: Issues and challenges. Foundation paper number 1.

Eurofound (2015), Upgrading or polarisation? Long-term and global shifts in the employment structure: European Jobs Monitor 2015, Publications Office of the European Union, Luxembourg.

European Commission (2010), Communication from the Commission Europe 2020. A strategy for smart, sustainable and inclusive growth, $\operatorname{COM(2010)} 2020$ final // http://eur-lex.europa.eu/legal-content/EN/TXT/PDF/?uri=CELEX:52 010DC2020\&from=en (refered on 15/02/2016).

European Commission (2013), Draft Joint Employment Report accompanying the Communication from the Commission on Annual Growth Survey 2014, COM(2013) 801 final // http://ec.europa.eu/europe2020/pdf/2014/jer2014_en.pdf (refered on 15/02/2016).

Eurostat Statistics Explained (2016), Quality of life indicators // http://ec.europa.eu/eurostat/statistics-explained/index. php/Quality_of_life_indicators (refered on 5/03/2016).

Flynn, P., Berry, D., Heitz, T. (2002), Sustainability and life indicators: toward the integration of economic, social and environment measures. Indicators, The Journal of Social Health, no. 1 (4), pp. 19-39.

Hagerty, M. R., Cummins, R., Ferriss, A. L., Land, K., Michalos, A., Peterson, M., Sharpe, A., Sirgy, M. J., and Vogel, J. (2001), Quality-of-life indexes for national policy: review and agenda for research, Social Indicators Research, no. 55(1), pp. 1-96.

Layard, R. (2005), Happiness - Lessons from a New Science, The Penguin Press.

Lisauskaite, V. (2010), Lietuvos gyventojų pajamų ir vartojimo diferenciacija, Business: Theory and Practice, no 11(3), pp. 266-278.

Mackonis, A. (2012), Ekonominių laimés rodiklių pagristumo ir patikimumo problema, Politologija, no. 1 (65), pp. 93-112.

Norberg, J. (2010), GDP and Its Enemies: The Questionable Search for a Happiness Index. Policy Brief, The Centre for European Studies.

Răileanu Szeles, M. (2009), On the Quality of Employment in the European Union, Bulletin of the Transilvania University of Brasov, Vol. 2, no. 51, Series V .

Second European Quality of Life Survey - First Findings (2009), // http://www.eurofound.europa.eu/pubdocs/2008/52/ en/1/EF0852EN.pdf (refered on 15/02/2016). 
Sehnbruch, K. (2004), From the Quantity to the Quality of Employment: An Application of the Capability Approach to the Chilean Labor Market. Working papers series, No 9, Centre for Latin American Studies, University of California, Berkeley.

Statistics Lithuania (2016), Official statistics portal // http://www.stat.gov.lt/en/home (refered on 1/04/2016).

Stiglitz, J. E., Sen, A., Fitoussi, J. P. (2009), Report by the Commission on the Measurement of Economic Performance and Social Progress // http://epp.eurostat.ec.europa.eu/portal/page/portal/gdp_and_beyond/documents/Stigliz_Sen_ Fitoussi_report_14092009.pdf (refered on 15/02/2016).

Vesan, P., Bizzotto, G. (2011), Quality of Life in Europe. Conceptual approaches and empirical definitions. Version 1: January 2011 Moncalieri, January 2011 A working paper for Workpackage 4 of the WALQING Project, SSH-CT-2009-244597 // http://www.walqing.eu/_(refered on 15/02/2016). 